\title{
Energy viability of Mimosa tenuiflora and Anacardium occidentale for brick firing in Rio Grande do Norte, Brazil
}

\author{
Viabilidade energética de Mimosa tenuiflora e Anacardium occidentale \\ para queima de tijolos no Rio Grande do Norte, Brasil
}

\begin{abstract}
Cynthia Patricia de Sousa Santos ${ }^{1}$ (D), Rosimeire Cavalcante dos Santos ${ }^{1}$ (D), Mateus Alves Magalhães ${ }^{4}$ (1), Damião Ferreira da Silva Neto ${ }^{1}$ (B)

${ }^{1}$ Universidade Federal do Rio Grande do Norte - UFRN, Macaíba, RN, Brasil

${ }^{2}$ Universidade Federal de São João Del-Rei - UFSJ, Sete Lagoas, MG, Brasil

${ }^{3}$ Universidade Federal do Espírito Santo - UFES, Jerônimo Monteiro, ES, Brasil

${ }^{4}$ Universidade Federal de Viçosa - UFV, Viçosa, MG, Brasil
\end{abstract} Renato Vinícius Oliveira Castro ${ }^{2}$ (), Sérgio Marques Júnior ${ }^{1}$ (D), Carlos Alberto Paskocimas ${ }^{1}$ (i) Ananias Francisco Dias Júnior ${ }^{3}$ (D), Ana Julia Miranda de Souza ${ }^{1}$ (D), Samara de Assis Carneiro ${ }^{1}$ (D),

How to cite: Santos, C. P. S., Santos, R. C., Castro, R. V. O., Marques Júnior, S., Paskocimas, C. A., Dias Júnior, A. F., Souza, A. J. M., Carneiro, S. A., Magalhães, M. A., \& Silva Neto, D. F. (2021). Energy viability of Mimosa tenuiflora and Anacardium occidentale for brick firing in Rio Grande do Norte, Brazil. Scientia Forestalis, 49(131), e3628.

https://doi.org/10.18671/scifor.v49n131.12

\begin{abstract}
The aim of this study was the technical evaluation of Mimosa tenuiflora and Anacardium occidentale wood for brick firing, by determining the wood consumption, brick quality and purchase cost of different species proportions. Three treatments (proportions of species) were adopted, namely 0JP - 100\% A. occidentale; 50JP - 50\% M. tenuiflora $+50 \%$ A. occidentale; and 100JP $-100 \%$ M. tenuiflora, with four replicates We determined the stacking factor, total wood consumption $\left(\mathrm{m}^{3}\right)$, volatile matter, ash and fixed carbon, higher calorific value, density, moisture, kiln loading frequency, temperature curve, relation between temperature and initial brick quality, brick classification after firing, wood purchase cost, gross revenue and net revenue. Data were submitted to the Lilliefors and Cochran tests and analysis of variance by the F-test, while the means were compared using the Tukey test. The significance level of $5 \%$ was set for all cases. M. tenuiflora wood presented the best results of chemical composition (higher calorific value and basic density), and thus had the lowest consumption $\left(\mathrm{m}^{3}\right)$. The use of the $A$. occidentale for firing bricks is not recommended because despite having a lower purchase price, the energy characteristics of this wood increases the consumption and thus the total cost of purchasing this fuel.
\end{abstract}

Keywords: Wood consumption; Firewood cost; Energy efficiency; Brick.

\section{Resumo}

O objetivo deste estudo foi a avaliação técnica de madeiras de Mimosa tenuiflora e Anacardium occidentale para a queima de tijolos, por meio da determinação do consumo de madeira, qualidade do tijolo e custo de aquisição em diferentes proporções de espécies. Três tratamentos (proporções de espécies) foram adotados, a saber: 0JP - 100\% A. occidentale; 50JP - 50\% M. tenuiflora + 50\% A. occidentale; e 100JP-100\% $M$. tenuiflora, com quatro repetições. Determinamos o fator de empilhamento, consumo total de madeira $\left(\mathrm{m}^{3}\right)$, matéria volátil, cinzas e carbono fixo, maior poder calorífico, densidade, umidade, frequência de carregamento do forno, curva de temperatura, relação entre temperatura e qualidade inicial do tijolo, classificação do tijolo após a queima, custo de aquisição da madeira, receita bruta e receita líquida. Os dados foram submetidos aos testes de Lilliefors e Cochran e análise de variância pelo teste F, enquanto as médias foram comparadas pelo teste de Tukey. O nível de significância de 5\% foi estabelecido para

Financial support: Coordenação de Aperfeiçoamento de Pessoal de Nível Superior - Brasil (CAPES) - Código Financeiro 001.

Conflict of interest: Nothing to declare.

Correspondig author: cynthiapss@live.com

Received: 13 October 2020.

Accepted: 06 January 2021.

Editor: Paulo Henrique Müller Silva.

(c) This is an Open Access article distributed under the terms of the Creative Commons Attribution License, which permits unrestricted use, distribution, and reproduction in any medium, provided the original work is properly cited. 
todos os casos. A madeira de M. tenuiflora apresentou os melhores resultados de composição química (maior poder calorífico e densidade básica) e, portanto, apresentou o menor consumo $\left(\mathrm{m}^{3}\right)$. O uso da A. occidentale para queima de tijolos não é recomendado, pois apesar de ter um preço de compra inferior, as características energéticas desta madeira aumentam o consumo e consequentemente o custo total de aquisição deste combustível.

Palavras-chave: Consumo de madeira; Custo da lenha; Eficiência energética; Tijolo.

\section{INTRODUCTION}

Brazil has more than 7,000 companies engaged in making red ceramics, with a substantial role in the country's economic activity, accounting for $1 \%$ of gross domestic product (GDP) (Rodrigues Neto, 2014; Serviço Brasileiro de Apoio às Micro e Pequenas Empresas, 2015). The country's Northeast region is one of the leaders in producing red ceramics, with the state of Rio Grande do Norte standing out with 186 companies and an average production of 111,000 bricks per month (Schwob et al., 2017).

Faced with national economic restrictions and the global effort to reduce carbon dioxide emissions, the red ceramic industry has been searching for ways to maintain productivity and sustainability, such as the use of more efficient and renewable energy sources, like biomass (Silva et al., 2017; Welfle, 2017). In Rio Grande do Norte, the main energy source for drying and firing of ceramic products is wood, for which the annual demand is $1.58 \times 10^{6} \mathrm{~m}^{3}$ (Schwob et al., 2017).

Half of this wood is derived from sustainable forest management undertakings in the Caatinga biome, unmanaged native forests and exploitation of the exotic plant species Prosopis juliflora (Schwob et al., 2017). The use of managed native species depends on payment of environmental fees, and the species in greatest demand is $M$. tenuiflora (black jurema), due to high abundance and characteristics that favor the production of energy (Galdino et al., 2014; Santos et al., 2013; Schwob et al., 2009). The remaining 50\% comes from plant residues (Schwob et al., 2017).

Plant residues are preferred as energy source, such as the residue left after pruning of A. occidentale (cashew tree), due to the lower cost and exemption from presenting the Forest Origin Document (DOF) (Sousa Júnior, 2018). However, the energy production properties A. occidentale wood are inferior to those of native wood (Instituto Nacional de Tecnologia, 2016).

The quality of the wood used as a fuel source is one of the factors that influences the consumption of firewood, as well as the productivity and quality of the ceramic pieces, given that the amount of heat supplied and the stability of the temperature influence the quality parameters (Punnarapong et al., 2017; Nascimento, 2015).

Although the wood used in brick making is characterized as a renewable energy source, it is necessary to evaluate the efficiency of the species chosen, in terms of cost and energy output. This highlights the need for studies to identify how this fuel performs, ultimately to reduce consumption and purchase cost while maintaining the quality of the ceramic pieces. This is especially important with regard to the use of native Caatinga wood.

Even though the purchase cost of native wood is higher than the cost of forest residues, the use of the M. tenuiflora wood, even in the same proportions as A. occidentale wood, can reduce the total consumption and cost for brick companies. In addition, it can also enhance the quality of the product, providing more high-quality pieces due to the superiority of this species' energy properties.

Therefore, the objective of this work was carry out the technical evaluation of $M$. tenuiflora and $A$. occidentale for the firing of bricks, in order to determine the wood consumption, quality of the ceramic pieces, and cost of acquisition for use in different species proportions.

\section{MATERIAL AND METHODS}

The study was carried out in a red ceramic factory located in the the municipality of Apodi, Rio Grande do Norte State. A multi-chamber brickmaking kiln was used for the production of 
type 19 bricks, with dimensions $9 \mathrm{~cm}$ thick $\times 19 \mathrm{~cm}$ long $\times 19 \mathrm{~cm}$ high, made from the same batch of clay.

The firing process in this type of kiln begins with the transfer of heat from the previous chamber (in the cooling process) to the working chamber through distribution channels. The chamber that receives the heat starts the heating phase, and the temperature stabilizes at around $500^{\circ} \mathrm{C}$.

After this phase, the wood is deposited in the chamber to promote combustion, thus reaching the firing temperature of $900^{\circ} \mathrm{C}$, which must remain stable for 20 hours. Therefore, the person responsible for the process monitors the temperature by means of a thermocouple system attached to the kiln chambers, and periodically manually supplies the kiln with wood to maintain the temperature at $900^{\circ} \mathrm{C}$.

After this 20-hour period, the chamber's cooling process begins, with the supply of firewood suspended, followed by opening channels for the heating phase of the next chamber and collection of the bricks produced, to classify them as first or second quality.

To evaluate the performance of the wood, three treatments were adopted (proportion the wood of $M$. tenuiflora and $A$. occidentale): 0JP - $100 \% A$. occidentale from a specific batch; 50JP - 50\% M. tenuiflora from a specific batch $+50 \% \mathrm{~A}$. occidentale from a specific batch; and $100 \mathrm{JP}-100 \%$ M. tenuiflora from a specific batch.

The option for $A$. occidentale wood as control treatment was due to the fact that this company usually uses this species. In addition, four replications were used for each treatment (four batches of brick firing per treatment), and the wood mixing was performed based on volume.

The wood pieces used in the firing process were arranged in the yard, one on top of the other, forming stacks of specific dimensions (approximately $4 \mathrm{~m}$ in length $\times 1.75 \mathrm{~m}$ in height). These dimensions were used as a volume parameter for treatments.

After the organization of the materials, a $1 \mathrm{~m}^{2}$ pattern was used, positioned in the central part of each pile where the pieces of wood located inside the pattern were marked with paint. Each marked piece was measured regarding cross-sectional area $\left(\mathrm{m}^{2}\right)$ at the ends and in the central part, and length $(\mathrm{m})$, as shown in Figure 1.

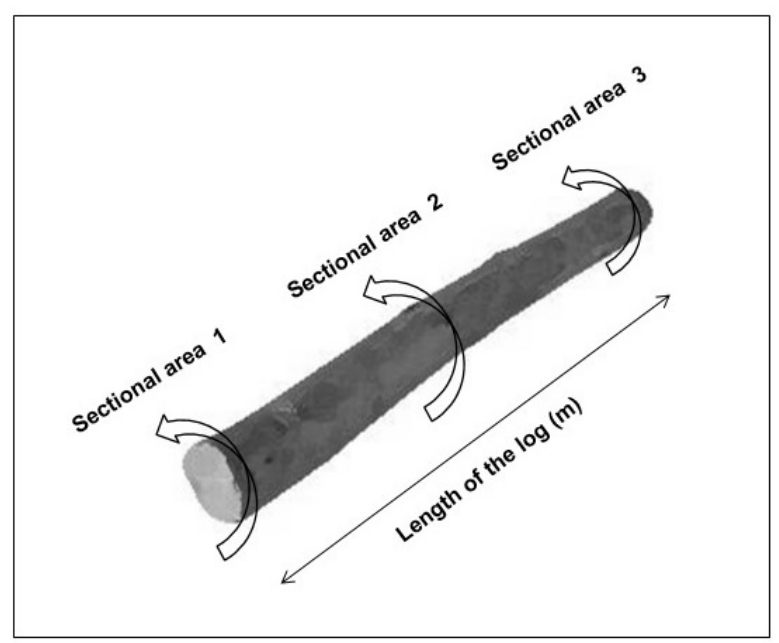

Figure 1 Illustration of wooden log measurement to determine the stacking factor.

The cross-sectional area and length of each piece were used to define the volume of wood in each stack through statistical analysis. The wood volume in each stack was obtained by the sum of the volume of the logs using Equation 1 (Newton's method):

$V\left(m^{3}\right)=\frac{S A_{1}+4 * S A_{1 / 2}+S A_{3}}{6} * L$ 
Where: SAi = cross-sectional areas at the ends (1 and 3) and in the central part (2) of each log $\left(\mathrm{m}^{2}\right)$; and $\mathrm{L}=$ length of the $\log (\mathrm{m})$.

The stacking factor of each stack was determined using Equation 2, dividing the stacked volume (st) ( $1 \mathrm{~m}^{2} \mathrm{x}$ average length of the logs) by the volume $\left(\mathrm{m}^{3}\right)$ obtained in the cubage of the logs:

$F e=\frac{\text { Stacked volume }(\mathrm{st})}{\text { Solid volume }\left(\mathrm{m}^{3}\right)}$

Where: Fe: stacking factor (st $\mathrm{m}^{-3}$ ).

Thus, the determination of the total average consumption of wood $\left(\mathrm{m}^{3}\right)$ per replication was carried out by the quotient between the stacked volume (st), not considering the leftover wood from each firing, and the stacking factor:

$V\left(m^{3}\right)=\frac{\text { Stacked volume }(s t)}{F e}$

The biomass was characterized through the analysis of the volatile materials, concentration of ashes and fixed carbon according to the standard NBR 8112 (Associação Brasileira de Normas Técnicas, 1986); higher calorific value according to the recommendations of NBR 8633 (Associação Brasileira de Normas Técnicas, 1984), using an adiabatic calorimeter; basic density, measured according to NBR 11941 (Associação Brasileira de Normas Técnicas, 2003a) using the water immersion method; and moisture content, which was estimated according to NBR 14929 (Associação Brasileira de Normas Técnicas, 2003b).

The frequency of supplying the combustion chambers was determined according to notes taken during the process, and the temperature curve was determined based on access to the data registered by the computer system connected to the chambers. From this information, the best maximum temperature was obtained for producing the greatest amount of prime quality pieces.

The quality of the bricks was determined after the firing process and cooling of the chambers, by counting and classifying the bricks in question. The classification was determined based on the color and the presence or absence of tortuosity in the ceramic piece, as follows: first grade (pieces with red color and lacking tortuosity); and second grade (pieces without red color and, or with tortuosity), and broken pieces. The company where the study was conducted only sells first-grade pieces.

The cost evaluation was based on the company data: the maximum and minimum costs for the purchase of firewood in 2019 for each species studied according to wood consumption in steres - st. The income was estimated from the maximum and minimum sales prices obtained per thousand units in the same year, for the respective production of premium grade bricks. Income from sales of byproducts was not considered.

As normal, costs are not incurred at the same time as sales revenue is received. Thus, for the purpose of analysis of net income, it was necessary to calculate the present value of costs and income (values considered at time zero) through a net present value factor based on compound interest. This procedure was necessary because the income is obtained with $60 \%$ of the cost in the act of the delivery and the remainder payable in 30 days (the value considered in period 1 ). In order to carry out this updating, a discount of $0.96 \%$ per month was applied, based on the interest rates applied by the National Bank for Economic and Social Development (BNDES) for financing of projects in the red ceramic industry (Moura, 2014).

All estimates were based on monthly values. To estimate the monthly expenses, only the costs of electric energy ( $R \$ 18,000.00)$ ), labor ( $R \$ 70,000.00)$, fuel $(R \$ 20,000.00)$ and wood (cost depending on the species used). The company carries out an average of 55 firings a month, which was the value used to estimate of monthly costs and income. 
The total net income was determined by the difference between the total monthly income and the monthly costs, according to the worst-case scenario (least total income and greatest cost) and the best-case scenario (greatest total income and least cost).

The experimental design was completely randomized with three treatments (proportions of $M$. tenuiflora wood to $A$. occidentale wood), with four replications (firings). The data were first submitted to the Lilliefors test to assess normality and the Cochran test to assess homogeneity of variance. Subsequently, analysis of variance was carried out through the F-test and the means were compared by the Tukey test. The level of significance was considered $5 \%$ throughout. The statistical analysis was conducted with the assistance of the R 2.131 software.

\section{RESULTS AND DISCUSSION}

Knowledge about the stacking factor (Figure 2 ) is important to estimate the average consumption of wood $\left(\mathrm{m}^{3}\right)$ in the brick firing process. The stacking factor was different in the stacks of $A$. occidentale wood $\left(3.48 \mathrm{st} \mathrm{m}^{-3}\right)$ and $M$. tenuiflora $\left(3.69 \mathrm{st} \mathrm{m}^{-3}\right.$ ) and, consequently the

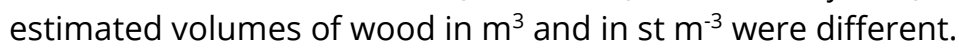

The organization of the wood stacks of the different treatments, although having similar dimensions, had different volumes, considering the quantity of empty spaces between the pieces of wood, which can be estimated by the stacking factor.

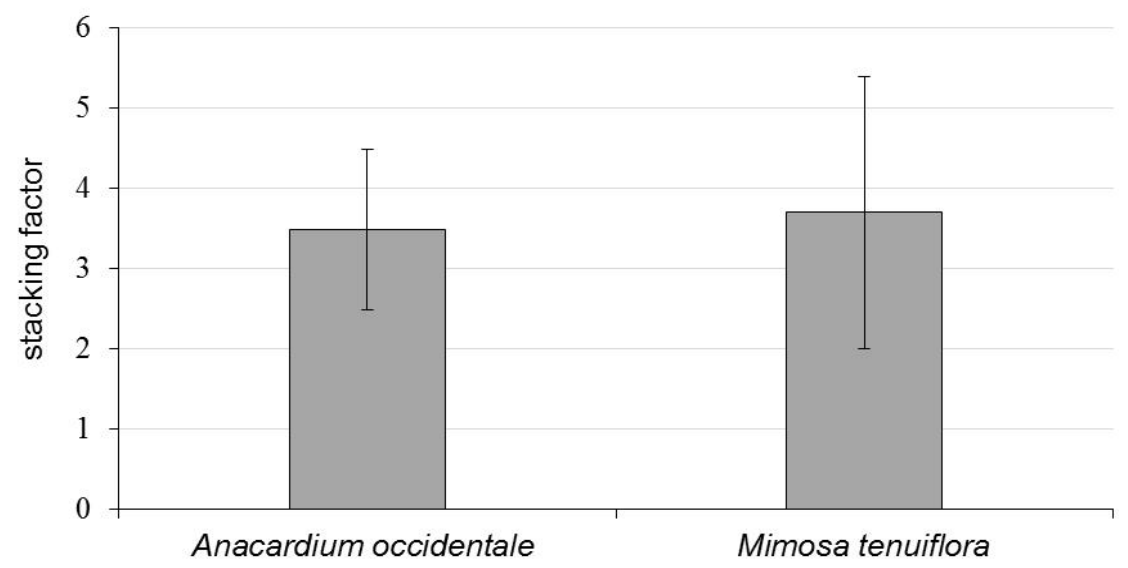

Figure 2 Stacking factor between the pieces of wood in the pile with known dimensions, obtained for the species $A$. occidentale and M. tenuiflora

The M. tenuiflora stacks had a larger stacking factor $\left(3.69 \mathrm{st}^{-3}\right)$, as observed in Figure 3 . In the Caatinga Forest Management Plan of Pernambuco, the stacking factor of $3.32 \mathrm{st} \mathrm{m}^{-3}$ is used for species included in the plan (Meunier et al., 2018). This higher stacking factor is due to the two main characteristics of $M$. tenuiflora, which typically has bent trunks with small diameters (Paula Neto et al., 1993, cited in Nunes \& Soares, 2017; Lopes et al., 2015).

The total average consumption of wood in treatment 0JP was greatest, requiring an average burning of $5.49 \mathrm{~m}^{3}$ of $A$. occidentale wood. In treatment 50JP, it was possible to reduce the volume of $A$. occidentale to $1.71 \mathrm{~m}^{3}$, totaling $3.42 \mathrm{~m}^{3}$ of wood consumed. The average consumption in treatment 100JP was lowest, with total burning of $2.68 \mathrm{~m}^{3}$ of M. tenuiflora wood (Figure 3). 


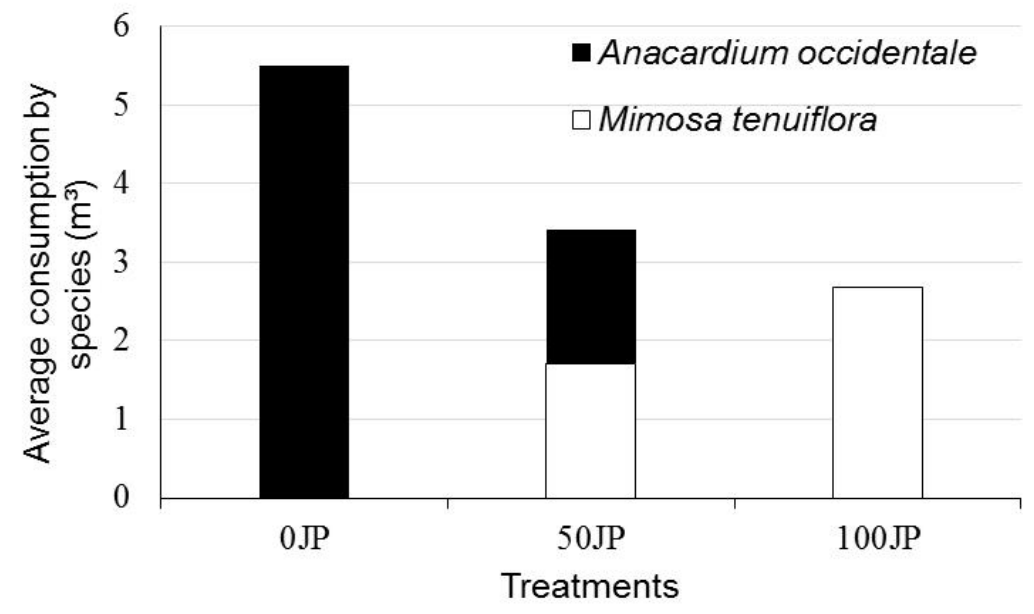

Figure 3 Total average consumption of wood in $\mathrm{m}^{3}$ during the firing of bricks according to the following treatments: 0JP - 100\% A. occidentale; 50JP - 50\% A. occidentale and 50\% M. tenuiflora; and 100JP - 100\% M. tenuiflora.

Based on this, it was possible to determine the consumption of wood in $\mathrm{m}^{3}$ and there was a reduction of $38 \%$ in the wood consumption in treatment 50JP and $51 \%$ in treatment $100 \mathrm{JP}$. The fuel consumption is a factor directly correlated to the quality of the wood for the generation of energy, which can be influenced by the chemical components present during firing.

We found significant differences in the contents of volatile materials and fixed carbon of the occidentale and tenuiflora species. Table 1 presents the amounts of the respective components of $A$. occidentale and $M$. tenuiflora wood, according to each treatment.

Table 1 Immediate chemical composition of $A$. occidentale and M. tenuiflora wood.

\begin{tabular}{|c|c|c|c|c|c|c|c|}
\hline \multirow{2}{*}{ Treatment } & \multirow{2}{*}{ Species } & \multicolumn{2}{|c|}{ VMC (\%) } & \multicolumn{2}{|c|}{$A C z(\%)$} & \multicolumn{2}{|c|}{ FCC (\%) } \\
\hline & & Mean & SD & Mean & SD & Mean & SD \\
\hline OJP & A. occidentale & $82.88 a$ & \pm 1.54 & $0.92 a$ & \pm 0.41 & $16.20 c$ & \pm 1.48 \\
\hline \multirow{2}{*}{ 50JP } & A. occidentale & $83.05 a$ & \pm 1.88 & $0.92 a$ & \pm 0.21 & $16.04 \mathrm{c}$ & \pm 1.88 \\
\hline & M. tenuiflora & $79.41 b$ & \pm 1.91 & $0.85 a$ & \pm 1.91 & $19.75 b$ & \pm 2.09 \\
\hline $100 \mathrm{JP}$ & M. tenuiflora & $77.72 \mathrm{c}$ & \pm 2.58 & $0.66 a$ & \pm 0.22 & $21.62 a$ & \pm 2.62 \\
\hline
\end{tabular}

$\mathrm{VMC}=$ Volatile matter content, $\mathrm{ACz}=$ Ash content, $\mathrm{FCC}=$ Fixed carbon content. Means followed by the same letters between the species for the same area and variable do not differ at $5 \%$ significance by the Tukey test.

The contents of volatile materials of $M$. tenuiflora were favorable for its use as fuel due to its low contents, providing longer supply of energy during combustion, besides facilitating the ignition process. Otherwise, oxidation and fast release of energy occurs (Brito \& Barrichelo, 2006; Juizo et al., 2017).

After firing of $A$. occidentale, traces of gummy resin were found due to exposure of wood to high temperatures. This resin was difficult to remove. Hence, the value of the ash content for this species, although it did not statistically differ from that of $M$. tenuiflora, can be higher because of the presence of this resin in the occidentale wood. The higher ash content can jeopardize the energy production and the interchange of heat, because of the inorganic composition and the solidification of this element, which then requires the kiln and ash pits to be cleaned more frequently (Ponte et al., 2019).

According to the results of fixed carbon, treatments 50JP and 100JP presented higher calorific value, due to the presence of the $M$. tenuiflora, since high fixed carbon content is associated with slower and more efficient firing process in terms of energy (Santos et al., 
2019), although the ideal range for the fixed carbon content is around $15 \%$ to $25 \%$ according to Brito \& Barrichelo (1982). This was true of all treatments. The slower burning of a fuel is preferable in the production of bricks, since the longer the product is exposed to the ideal stable temperature, the better the quality of the product will be (Cabó et al., 2015).

Besides these contents, there was a difference in the higher calorific power, and the basic density of the species, in which M. tenuiflora presents greater values, according to Table 2 . Even with low moisture content, the treatment 0JP had a higher consumption of wood, which points to the need to ascertain the energy characteristics of the wood.

Table 2 Higher calorific power, basic density and moisture of $A$. occidentale and M. tenuiflora wood.

\begin{tabular}{|c|c|c|c|c|c|c|c|}
\hline \multirow{2}{*}{ Treatment } & \multirow{2}{*}{ Species } & \multicolumn{2}{|c|}{ HCP $\left(\right.$ kcalkg $\left.^{-1}\right)$} & \multicolumn{2}{|c|}{$B D\left(\mathrm{~g} / \mathrm{cm}^{3}\right)$} & \multicolumn{2}{|c|}{ M (\%) } \\
\hline & & Mean & SD & Mean & SD & Mean & SD \\
\hline OJP & A. occidentale & $4671 \mathrm{c}$ & \pm 26 & $0.43 b$ & \pm 0.07 & $14.3 c$ & \pm 3.4 \\
\hline \multirow{2}{*}{ 50JP } & A. occidentale & $4682 c$ & \pm 34 & $0.43 b$ & \pm 0.04 & $20.8 b c$ & \pm 20.3 \\
\hline & M. tenuiflora & $4763 b$ & \pm 98 & $0.80 a$ & \pm 0.06 & $33.5 a$ & \pm 25.3 \\
\hline $100 J P$ & M. tenuiflora & $4842 a$ & \pm 128 & $0.78 a$ & \pm 0.09 & $29.7 a b$ & \pm 22.5 \\
\hline
\end{tabular}

$\mathrm{BD}=$ Basic density, $\mathrm{HCP}=$ Higher calorific power, $\mathrm{M}=$ moisture. Means followed by the same letter between the species in the same area and variable do not differ at $5 \%$ significance by the Tukey test.

The basic density and higher heating value are parameters that influence the use of wood for the production of energy. M. tenuiflora has higher basic density $\left(0.80 \mathrm{~g} / \mathrm{cm}^{3}-50 \mathrm{JP}\right.$; $\left.0.78 \mathrm{~g} / \mathrm{cm}^{3}-100 \mathrm{JP}\right)$ compared to $A$. occidentale $\left(0.43 \mathrm{~g} / \mathrm{cm}^{3}-0 \mathrm{JP}\right.$ and $\left.50 \mathrm{JP}\right)$ and greater higher calorific value as well (4767 kcalkg-1 - 50JP; $\left.4842 \mathrm{kcalkg}^{-1}-100 \mathrm{JP}\right)$. According to Santos et al. (2016), M. tenuiflora wood presents high density and superior heating value, which means that it contains a greater amount of stored energy per cubic meter. This positively affects the results if the transportation of wood is considered, since when hauling $M$. tenuiflora wood there will be a higher quantity of energy transported than for $A$. occidentale wood.

Therefore the high consumption of the A. occidentale wood in the 0JP treatment can be associated with its low basic density and high upper calorific value. Although the 50JP treatment showed a reduction in consumption of fuel due to the favorable energy characteristics of $M$. tenuiflora, the low density of the $A$. occidentale may have contributed to the start of burning of $M$. tenuiflora. According to Machado Neto et al. (2015), high density makes starting the firing process more difficult, but after this phase there is more intense combustion.

During the entire firing process, the frequency of supplying the chamber was verified simultaneously with recording the temperature. The supply frequency was 41 times in the 0JP treatment, 36 in the 50JP treatment, and 29 in 100JP treatment. The supply rate is related to stabilization of the temperature.

These energy characteristics of the wood also affect the frequency of refueling the chambers. Based on the volatile matter, fixed carbon, basic density and higher calorific power parameters, the frequency of refueling in the 100JP treatment was 29 minutes on average, indicating that the energy of $A$. occidentale wood is released faster.

The continuous supply of heat during firing and the stabilization of temperature were elements that influenced the quality of the bricks in color and integrity. To identify the thermal profile of the chambers during the firing process, Figure 4 shows the temperatures obtained during the firing of bricks in the chamber at each replication of each treatment. 


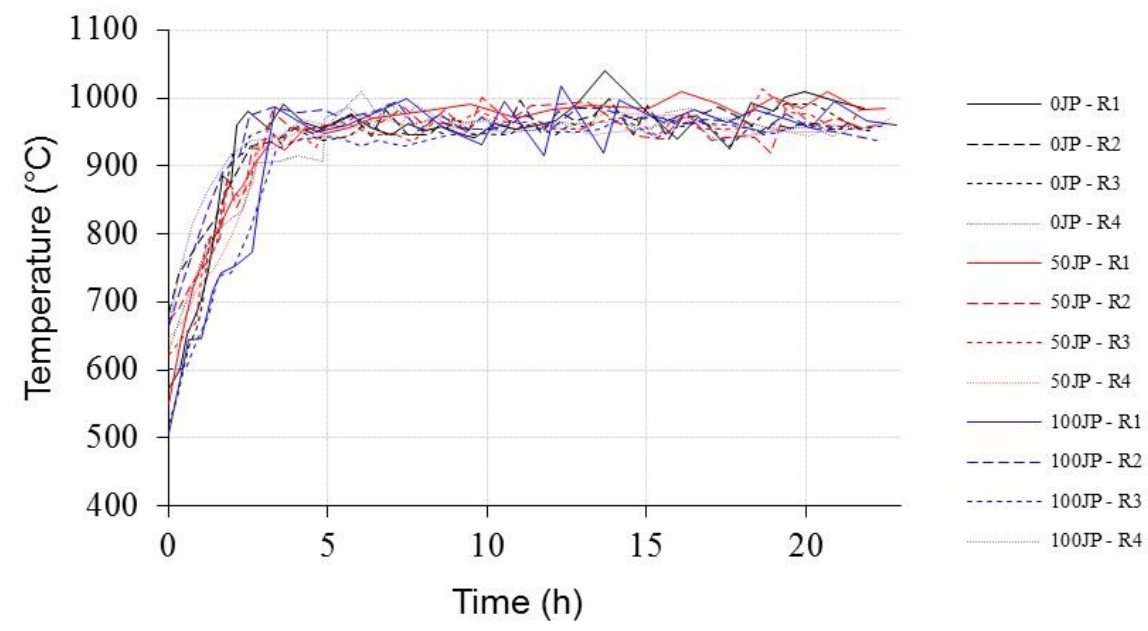

Figure 4 Thermal profile of the chambers during brick firing. In which: $\mathrm{R} 1=$ repetition $1, \mathrm{R} 2$ = repetition 2, R3 and R4 = repetition 4.

Based on the highest and lowest temperatures reached in the firing process in each treatment, we plotted a temperature curve as shown in Figure 5. The highest temperature reached when using only $A$. occidentale (0JP) wood was $1040^{\circ} \mathrm{C}$. For the treatments 50JP and $100 \mathrm{JP}$, the highest temperatures identified was $1010^{\circ} \mathrm{C}$ and $1020^{\circ} \mathrm{C}$, respectively. The lowest registered temperature was observed in the $100 \mathrm{JP}$ treatment: $902^{\circ} \mathrm{C}$.
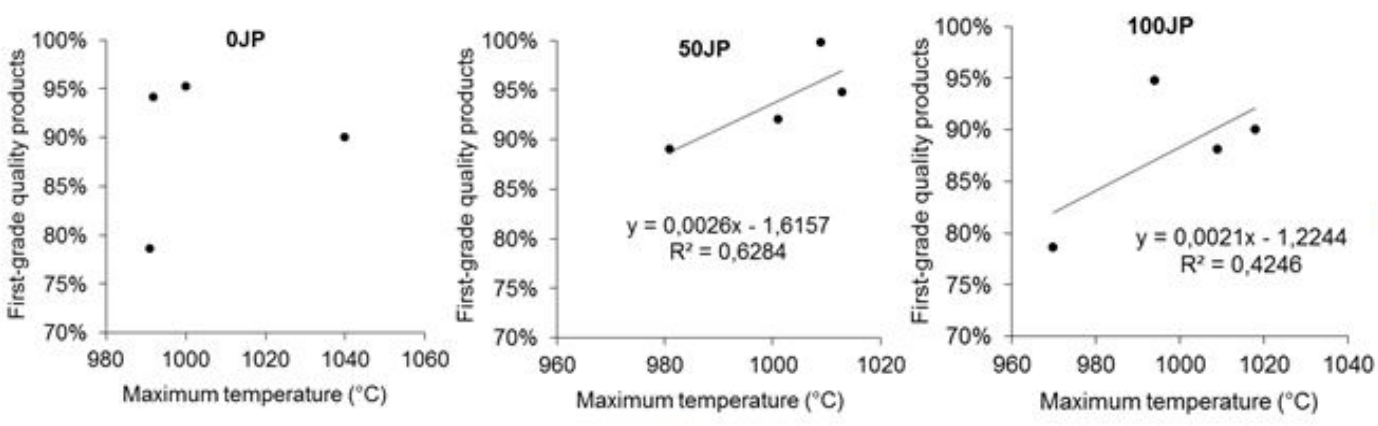

Figure 5 Percentage of first-grade products based on the maximum temperature obtained by the supply of heat to the wood.

As the temperature rises, the percentage of first-grade bricks increased in the 50JPC and 100JP treatments. However, 50JP stood out with the production of first quality bricks, which was close to $100 \%$ when using a temperature of $1010^{\circ} \mathrm{C}$. In the $100 \mathrm{JP}$ treatment, there was a reduction in the brick quality when the temperature reached $1000^{\circ} \mathrm{C}$.

Generally speaking, with respect to classification of the bricks after firing according to each treatment, on average in the 0JP treatment (100\% A. occidentale), $89 \%$ of the bricks were first-grade quality and $10 \%$ were second-grade. In the 50JP treatment, however (50\% A. occidentale and $50 \%$ M. tenuiflora), $94 \%$ of the bricks were first grade and $6 \%$ were second grade. In the treatment that utilized only M. tenuiflora wood (100JP), $88 \%$ of the bricks had firstgrade quality and $12 \%$ second-grade quality. In neither treatment were broken pieces observed.

Although there is a reasonable appeal for the use of wood as a clean and renewable energy source, it is important to verify its efficiency in economic terms. According to Table 3 , in treatments 50JP and 100JP, the acquisition cost of this fuel was lower. 
Table 3 Estimated acquisition costs of wood per batch according to the treatments of this study.

\begin{tabular}{|c|c|c|c|c|c|c|c|}
\hline \multirow{2}{*}{ Treatment } & \multirow{2}{*}{ Species } & \multirow{2}{*}{ CON(st) } & \multicolumn{2}{|c|}{ Purchase(R\$) } & \multicolumn{2}{|c|}{ Total(R\$) } & \multirow{2}{*}{ RED(\%) } \\
\hline & & & MIN & MAX & MIN & MAX & \\
\hline OJP & A. occidentale & 19,15 & 21,00 & 25,00 & 402,15 & 478,75 & - \\
\hline \multirow{2}{*}{ 50JP } & A. occidentale & 6,34 & 21,00 & 25,00 & 124,74 & 148,50 & \multirow{2}{*}{$17,16 \%$} \\
\hline & M. tenuiflora & 5,94 & 32,00 & 40,00 & 202,88 & 253,60 & \\
\hline $100 J P$ & M. tenuiflora & 9,91 & 32,00 & 40,00 & 317,12 & 396,40 & $19,00 \%$ \\
\hline
\end{tabular}

$\mathrm{CON}=$ consumption of wood in each treatment in st, MAX = maximum purchase cost in 2019, MIN = minimum purchase cost in 2019, RED = percentage of wood acquisition cost reduction compared to treatment 0JP.

With respect to purchase costs, although $A$. occidentale wood is more commonly used for ceramic firing because of its lower purchase price, the consumption of this fuel can be higher because it has lower energy efficiency, which affects the final cost of the product. Consequently, the use of the $M$. tenuiflora wood as an energy source in the firing process of bricks reduces the wood cost and generates savings for the company of around $17 \%$ to $19 \%$ per working chamber. In Table 4, it is possible to observe the estimate of the revenue of first quality products according to the performance of each treatment.

Table 4 Estimated revenue from sale of bricks per batch based on the amount of first-grade products.

\begin{tabular}{cccccccc}
\multirow{2}{*}{ Treatment } & \multirow{2}{*}{ Species } & \multicolumn{2}{c}{ QUANT } & & \multicolumn{2}{c}{ SALE(R\$) } & \multirow{2}{*}{ TOT(R\$) } \\
\cline { 3 - 4 } & & MIN & MAX & & MIN & MAX & \\
\hline 0JP & $89 \%$ & 290.00 & 340.00 & & $2,581.00$ & $3,026.00$ & - \\
50JP & $94 \%$ & 290.00 & 340.00 & & $2,726.00$ & $3,196.00$ & $5.62 \%$ \\
100JP & $88 \%$ & 290.00 & 340.00 & & $2,552.00$ & $2,992.00$ & $-1.12 \%$ \\
\hline
\end{tabular}

QUANT = percentage of first-grade pieces, MAX = maximum sale price of a thousand bricks in 2019, MIN = minimum price of sale of a thousand bricks in 2019, TOT = total revenue from each treatment, RED = percentage of increase or reduction of revenue compared to wood treatment 0JP.

Aside from the reduction of acquisition costs, there was also an increase of $2.70 \%$ in the revenue from selling the bricks, taking into consideration the use of the proportion of wood indicated in the 50JP treatment. However, in the 100JP treatment, a decline in the number of first-grade bricks caused a reduction in revenues. This may have been associated with refueling the chamber manually: when utilizing a different species, the temperature might have risen above the acceptable level, generating cracks and breaks in the bricks.

Thus, to calculate the net income, initially it was necessary to update the gross income to present value- as presented in Table 5.

Table 5 Adjustment of income from sale of bricks per firing (in $\mathrm{R} \$$ ).

\begin{tabular}{|c|c|c|c|c|c|c|c|c|}
\hline \multirow{2}{*}{ Treatment } & \multicolumn{2}{|c|}{ INC - 0 (R\$) } & \multicolumn{2}{|c|}{ INC - 1 (R\$) } & \multicolumn{2}{|c|}{ INC - 0,96\% (R\$) } & \multicolumn{2}{|c|}{ INC - PV (R\$) } \\
\hline & MIN & MAX & MIN & MAX & MIN & MAX & MIN & MAX \\
\hline OJP & $1,548.60$ & $1,815.60$ & $1,032.40$ & $1,210.40$ & $1,022.58$ & $1,198.89$ & $2,571.18$ & $3,014.49$ \\
\hline 50JP & $1,635.60$ & $1,917.60$ & $1,090.40$ & $1,278.40$ & $1,080.03$ & $1,266.24$ & $2,715.63$ & $3,183.84$ \\
\hline $100 J P$ & $1,531.20$ & $1,795.20$ & $1,020.80$ & $1,196.80$ & $1,011.09$ & $1,185.2$ & $2,542.29$ & $2,980.62$ \\
\hline
\end{tabular}

INC - $0=$ income at time zero or $60 \%$ of the total income, INC - $1=$ income at time 1 or $40 \%$ of the total income (30 days after delivery of the product), REC $-0.96 \%=$ income with discount of $0.96 \%$ per month, INC - PV $=$ total present value of income after adjustment.

It can be seen that even after updating the monetary value using the discount rate, the income (per firing) from the sales of bricks fired with $50 \% \mathrm{~A}$. occidentale and $50 \% \mathrm{M}$. tenuiflora (treatment 50JP) was higher than in the other treatments. However, it is necessary to consider 
the net income after the deductions of the company's expenses. Table 6 presents the results of the monthly total net income.

Table 6 Monthly net income from brick sales per treatment (in R\$).

\begin{tabular}{|c|c|c|c|c|c|c|c|c|}
\hline \multirow[b]{2}{*}{ Treatment } & \multicolumn{2}{|c|}{ Total monthly cost (R\$) } & \multicolumn{2}{|c|}{ Total monthly INC (R\$) } & \multicolumn{4}{|c|}{ Total monthly net INC (R\$) } \\
\hline & MIN & MAX & MIN & MAX & $\begin{array}{c}\text { Worst-case } \\
\text { scenario }\end{array}$ & $\%$ & $\begin{array}{l}\text { Best-case } \\
\text { scenario }\end{array}$ & $\%$ \\
\hline OJP & $130,118.25$ & $134,331.25$ & $141,415.08$ & $165,796.99$ & $7,083.83$ & - & $35,678.74$ & - \\
\hline 50JP & $126,019.10$ & $130,115.00$ & $149,359.74$ & $175,111.42$ & $19,244.24$ & 172 & $49,092.32$ & 38 \\
\hline 100JP & $125,441.60$ & $129,802.00$ & $139,826.14$ & $163,934.10$ & $10,024.14$ & 42 & $38,492.50$ & 8 \\
\hline
\end{tabular}

INC = income from sales of fired bricks per treatment, \% = percentage of increase in net monthly income in relation to treatment 0JP.

The use of legal native wood as a source of energy for brick firing produced a gain in the net monthly income, even in the worst-case scenario (highest cost and lowest income). The association of $A$. occidentale and $M$. tenuiflora (50JP) produced the highest monthly net income, and with the use of $M$. tenuiflora alone (100JP) it was necessary to make adjustments to the process, such as the time and temperature of firing, as well as standardization of supplying the kiln.

Moreover, to arrive at the net results, the costs of electric energy, labor, fuel and wood were considered, although other costs can also be included. In this way, we recommend that different processes be adopted depending on the species used as energy source, and further studies to evaluate the use of other species or biomass sources in the process of firing ceramic materials.

\section{CONCLUSIONS}

M. tenuiflora is a possible species for the production of energy for brick firing, since it has favorable characteristics for this purpose, namely reduction of wood consumption of the treatments 50JP and 100JP. Although the purchase price of $M$. tenuiflora is higher, the reduction of consumption per $\mathrm{m}^{3}$ saved money when considering the total costs.

Compared to $M$. tenuiflora, the purchase price of the A. occidentale wood is lower, but its energy characteristics, such as lower density, and especially smaller higher calorific power, increased the consumption of this fuel. Consequently, the total cost of purchasing A. occidentale is higher.

Furthermore, by combining $A$. occidentale with $M$. tenuiflora in the 50JP treatment, in addition to reducing the consumption of wood, the study showed an increase in the production of high-quality bricks at the maximum temperature of $1010{ }^{\circ} \mathrm{C}$. When using M. tenuiflora wood alone, modifications are recommended in the brick firing process, such as adjustments of sintering time, maximum temperature, and frequency of refueling, based on preliminary studies, in order to standardize this process, prevent temperatures from oscillating, and maintaining the integrity of the pieces, thus increasing the sales revenue.

\section{ACKNOWLEDGEMENTS}

This study was financed in part by the Office to Coordinate Improvement of University Personnel (CAPES) - Finance Code 001.

\section{REFERENCES}

Associação Brasileira de Normas Técnicas - ABNT. (1984). NBR 8633: Carvão vegetal - Determinação do poder calorífico. Rio de Janeiro: ABNT. 
Associação Brasileira de Normas Técnicas - ABNT. (1986). NBR 8112: Carvão vegetal - Análise Imediata. Rio de Janeiro: ABNT.

Associação Brasileira de Normas Técnicas - ABNT. (2003a). NBR 11941: Madeira - determinação da densidade básica. Rio de Janeiro: ABNT.

Associação Brasileira de Normas Técnicas - ABNT. (2003b). NBR 14929: madeira: determinação da umidade da madeira. Rio de Janeiro: ABNT.

Moura, A. (2014, December 1). Crédito auxilia indústrias de cerâmica vermelha. Associação Nacional da Indústria Cerâmica - ANICER. Retrieved in 2020, November 20, from https://www.anicer.com.br/revista-anicer/revista-91/credito-auxilia-industrias-de-ceramicavermelha/.

Brito, J. O., \& Barrichelo, L. E. G. (1982). Aspectos técnicos da utilização da madeira e carvão vegetal como combustíveis. In Anais do $2^{\circ}$ Seminário de Abastecimento Energético Industrial com Recursos Florestais (pp. 101-37). São Paulo: ESALQ-USP.

Brito, J. O., \& Barrichelo, L. E. G. (2006). Comportamento isolados da lignina e da celulose da madeira frente à carbonização (Circular Técnica, 28, 4 p.). Piracicaba: ESALQ.

Cabó, A., Lima, R., Lopes, D., \& Bezerra, L. (2015). Sistema microcontrolado de baixo custo para o monitoramento de altas temperaturas em fornos da indústria de cerâmica vermelha. Revista de Sistemas e Computação, 5(1), 15-25.

Galdino, J. N., Tavares, M. A. M. E., Leal, M. L., Pinheiro, A. S., Lima, A. G. S. (2014). A indústria de cerâmica vermelha no Rio Grande do Norte e no Baixo-Açu Potiguar. In S. R. L. Tavares (Ed.), Biocombustíveis sólidos (Cap. 7, pp. 220-258). Brasília: Editora do IFRN.

Instituto Nacional de Tecnologia - INT. (2016). Manual para escolha da biomassa combustível em indústrias de cerâmica. Rio de Janeiro: INT.

Juizo, C. G. F., Lima, M. R., \& Silva, D. A. (2017). Qualidade da casca e da madeira de nove espécies de Eucalipto para produção de carvão vegetal. Revista Brasileira de Ciências Agrárias, 12(3), 386-90. http://dx.doi.org/10.5039/agraria.v12i3a5461.

Lopes, P. J. G., Calegari, L., Calegari, C. C. A., Oliveira, E., Stangerlin, D. M., \& Gatto, D. A. (2015). Produtividade em Casca e Taninos Condensados de Jurema-Preta. Revista Nativa, 3(2), 95-101. http://dx.doi.org/10.14583/2318-7670.v03n02a04.

Machado Neto, A. P., Brandão, C. F. L. S., Duarte, B., Almir, J., Marangon, L. C., \& Feliciano, A. L. P. (2015). Densidade e poder calorífico como base para prevenção de incêndios florestais sob linhas de transmissão. Nativa (Sinop), 3(1), 10-15. http://dx.doi.org/10.14583/2318-7670.v03n01a02.

Meunier, I. M. J., Ferreira, R. L. C., \& Silva, J. A. A. (2018). O licenciamento de Planos de Manejo Florestal da Caatinga assegura sua sustentabilidade? Pesquisa Florestal Brasileira, 38, 1-7.

Nascimento, C. A. (2015). Estudo da reengenharia de fornos cerâmicos com crivamento: uma oportunidade real de melhoria da sustentabilidade (Dissertação de mestrado). Universidade Federal do Paraná, Guarapuava.

Nunes, J. S., \& Soares, T. S. (2017). Estimativas volumétricas para um povoamento adensado de Eucalyptus SP. em regime de curta rotação. Revista de Agricultura Neotropical, 4(4), 77-86. http://dx.doi.org/10.32404/rean.v4i4.1661.

Paula Neto, F., Rezende, A. V., Campos, J. C. C., Rezende, J. L. P. (1993). Análise do comportamento dos fatores de empilhamento para Eucalyptus grandis. Revista Árvore,17(1), 45-59.

Ponte, M. R., Gadelha, A. M. T., Machado, Y. L., Lopes, A. A. S., Malveira, J. Q., Mazzetto, S. E., Lomonaco, D., \& Rios, M. A. S. (2019). Blendas de bagaço de cana-de-açúcar, podas de mangueira e cajueiro: caracterização das propriedades e investigação de seus potenciais energéticos. Matéria (Rio de Janeiro), 24(2), 1-12. http://dx.doi.org/10.1590/s1517-707620190002.0687.

Punnarapong, P., Promwungkwa, A., \& Tippayawong, N. (2017). Development and performance evaluation of a biomass gasification system for ceramic firing process. Energy Procedia, 110, 53-58. http://dx.doi.org/10.1016/j.egypro.2017.03.105.

Rodrigues Neto, A. (2014). Arranjos produtivos locais em russas-CE: o caso da cerâmica vermelha Abrão (Dissertação de mestrado). Universidade de Brasília, Brasília.

Santos, R. C., Carneiro, A. D. C. O., Damasceno, G. R. F., Castro, A. F. N. M., Castro, R. V. O., Da Costa, L. S., \& Costa, S. E. L. (2019). Efeito da variabilidade de resíduos madeireiros na produção e qualidade de briquetes. Advances in Forestry Science, 6(1), 529-534. http://dx.doi.org/10.34062/afs.v6i1.7145.

Santos, R. C., Carneiro, A. D. C. O., Pimenta, A. S., Castro, R. V. O., Marinho, I. V., Trugilho, P. F., Alves, I. C. N., \& Castro, A. F. N. M. (2013). Potencial energético da madeira de espécies oriundas de plano de 
manejo florestal no Estado do Rio Grande do Norte. Ciência Florestal, 23(2), 491-502. http://dx.doi.org/10.5902/198050989293.

Santos, R. C., Castro, R. V. O., Carneiro, A. D. C. O., Castro, A. F. N. M., Pimenta, A. S., Pinto, E. M., \& Marinho, I. V. (2016). Estoques de volume, biomassa e carbono na madeira de espécies da Caatinga em Caicó, RN. Pesquisa Florestal Brasileira, 36(85), 1-7. http://dx.doi.org/10.4336/2016.pfb.36.85.772.

Schwob, M. R. V., Henriques Júnior, M. F., Carlos, M. E. M., Pacheco, L. F. L., Cândido, R. S. (2017). Panorama do setor de cerâmica vermelha no Brasil. In M. F. Henriques Junior, \& J. A. P. Rodrigues (Orgs.), Cerâmica Vermelha: Projeto EELA no Brasil (pp. 11-33). Rio de Janeiro: INT/ MCTIC.

Schwob, M. R. V., Henriques Junior, M., \& Szklo, A. (2009). Technical potential for developing natural gas use in the Brazilian red ceramic industry. Applied Energy, 86(9), 1524-1531. http://dx.doi.org/10.1016/j.apenergy.2008.10.013.

Serviço Brasileiro de Apoio às Micro e Pequenas Empresas - SEBRAE. (2015). Boletim de Inteligência: construção civil. São Paulo: SEBRAE.

Silva, A. C., Méxas, M. P., \& Quelhas, O. L. G. (2017). Restrictive factors in implementation of clean technologies in red ceramic industries. Journal of Cleaner Production, 168, 441-451. http://dx.doi.org/10.1016/j.jclepro.2017.09.086.

Sousa Júnior, A. D. (2018). Documento de origem florestal - DOF: análise da comercialização de produtos florestais nativos legalizados no estado do Rio Grande do Norte (Dissertação de mestrado). Universidade Federal do Rio Grande do Norte, Macaiba.

Welfle, A. (2017). Balancing growing global bioenergy resource demands - Brazil's biomass potential and the availability of resource for trade. Biomass and Bioenergy, 105, 83-95. http://dx.doi.org/10.1016/j.biombioe.2017.06.011.

Authors' contributions: CPSS: writing, conceptualization, data curation, formal analysis, methodology; RCS, SM] and CAP: conceptualization, funding acquisition, supervision; RVOC: data curation, formal analysis, methodology; AFDJ: conceptualization, methodology, supervision; AJMS, SAC, MAM and DFSN: writing, methodology; supervision. 